\title{
PENGENDALIAN PERSEDIAAN PRODUK DROP CABLE DI PROYEK INSTALASI KABEL RUMAH DAN MIGRASI JARINGAN AREA BANDUNG (STUDI KASUS: PT INTI PERSERO)
}

\author{
Agung Dera Pradana ${ }^{1)}$, Leni Herdiani ${ }^{2)}$, Rohmana ${ }^{2)}$ \\ ${ }^{1)}$ PT. Inti Persero Bandung \\ ${ }^{2)}$ Fakultas Teknik, Prodi Teknik Industri Universitas Langlangbuana \\ e-mail: agungderapradana@gmail.com; leni.herdiani@unla.ac.id
}

\begin{abstract}
ABSTRAK
Persediaan merupakan suatu masalah yang kompleks dan penting untuk perusahaan karena menyangkut masalah-masalah optimasi dengan model kuantitatif sehingga diperlukan metode yang mengintegrasikan faktor-faktor model pesediaan. PT INTI (Persero) Terutama sebagai sistem integrator untuk pembangunan infrastruktur telekomunikasi di Indonesia (SBU Broadband) proyek instalasi kabel rumah dan migrasi jaringan, berdasarkan hasil analisis yang di lakukan khususnya di area proyek perusahaan belum dapat menentukan safety stock kabel yang ideal bagi teknisi instalasi kabel rumah dan migrasi, hal tersebut sering kali terjadi stock out di beberapa produk drop cable ketika ada permintaan dari teknisi yang berakibat terhadap pengeluaran cost persediaan yang tidak optimal. Maka perlu adanya pengendalian persediaan di lokasi area proyek sehingga di harapkan dapat diperoleh biaya yang minimum untuk biaya operasional persediaaan. Hasil dari penelitian menunjukan bahwa dengan menggunakan metode EOQ, diperoleh biaya yang harus dikeluarkan sebesar Rp. 31.327.642,61, frekuensi pemesanan sebanyak 8 kali dengan jumlah pemesanan 310 unit dan reorder point sebesar 64 unit.
\end{abstract}

Kata kunci: Jumlah Pemesanan, Pengendalian Persediaan, EOQ, Safety Stock, Reorder Point.

\begin{abstract}
Inventory is a complex and important problem for the company because it involves optimization problems with quantitative models so that a method is needed that integrates the availability model factors. PT INTI (Persero) Especially as a system integrator for telecommunication infrastructure development in Indonesia (SBU Broadband) home cable installation and network migration projects, based on the results of analysis carried out especially in the project area the company has not been able to determine safety cable cables that are ideal for cable installation technicians housing and migration, it often happens that there are stock outs in a number of drop cable products when there is a demand from technicians which results in unoptimal expenditure of inventory costs. Then it is necessary to control inventory at the location of the project area so that the minimum costs for the operational costs of the project can be obtained. The results of the study show that by using the EOQ method, the costs incurred are Rp. 31,327,642.61, the ordering frequency is 8 times with the order number of 310 units and reorder points of 64 units.
\end{abstract}

Keywords: Quantity Order, Inventory Control, EOQ, Safety Stock, Reorder Point.

\section{PENDAHULUAN}

Periode tahun 2012 - sekarang PT INTI (Persero) memantapkan langkahnya untuk memasuki bisnis solusi Engineering, sistem integrator dan pengembangan produk-produk genuine. Sebagai sistem integrator untuk pembangunan infrastruktur telekomunikasi di Indonesia, dalam hal ini khususnya di proyek modernisasi Jaringan fiber optic bagian instalasi kabel rumah dan migrasi (SBU broadband) yang di laksanakan di Bandung area, perusahaan belum dapat menentukan safety stock kabel yang ideal bagi teknisi instalasi kabel rumah dan migrasi, hal tersebut sering kali terjadi stock out di beberapa produk drop cable ketika ada permintaan dari teknisi. Sekilas cerita proyek instalasi kabel rumah dan migrasi jaringan ini merupakan proyek modernisasi jaringan yang di mitrakan PT Telkom Indonesia kepada PT INTI, di proyek ini PT INTI bertugas untuk mengganti kabel tembaga ke fiber optic dan memodernisasi perangkat dari perangkat lama ke yang baru khususnya. 
Pengendalian Persediaan Produk Drop Cable di Proyek Instalasi Kabel Rumah dan Migrasi Jaringan Area Bandung (Studi Kasus: PT Inti Persero)

Agung Dera Pradana, Leni Herdiani, Rohmana

pelanggan yang masih aktif menggunakan layanan dari telkom misalnya speedy maupun telepon dalam hal ini pelanggan tidak dibebankan biaya (gratis).

Proyek ini bertujuan agar pelanggan dapat menikmati layanan Indihome dari PT Telkom Indonesia serta satu alat dapat di pergunakan untuk tiga fungsi layanan seperti telepon, tv kabel, internet dan mengurangi dampak gangguan karena kualitas teknologi misalnya kualitas teknologi tembaga yang sudah menurun serta memberikan akses internet lebih cepat di bandingkan dengan teknologi sebelumnya. Namun dalam hal ini terdapat suatu resiko yang harus di jalani oleh PT INTI ialah dimana PT Telkom sendiri tidak memberikan data panjang kabel setiap rumah nya misalnya atas nama Bapak Aris alamat jalan Tegalega no 5 dengan panjang kabel 55 meter. Dengan tidak adanya data tersebut tentunya akan berdampak terhadap proses pengendalian persediaan kabel di PT INTI dan yang perlu di perhatikan pada saat uji terima PT Telkom hanya membayar jasa sesuai spesifikasi di lapangan.

Adapun contoh kasusnya ialah ketika teknisi membutuhkan drop cable ukuran 55 meter namun yang tersedia ialah drop cable dengan ukuran 100 meter karena kebutuhan urgent untuk melakukan instalasi kabel rumah maka teknisi terpaksa harus memakai stock drop cable yang tersedia tentunya hal tersebut akan berpengaruh terhadap cost yang di keluarkan perusahaan, dimana di ketahui bahwa harga drop cable ukuran 100 meter lebih mahal di banding drop cable dengan ukuran 55 meter, dalam hal ini PT Telkom tidak memberikan data panjang kabel dan pada saat uji terima Telkom hanya membayar sesuai speksifikasi di lapangan jika pelanggan tersebut ukuran panjang kabelnya 55 meter maka telkom akan membayar sesuai harga materialnya yaitu harga drop cable 55 meter walaupun saat pelakasanaan teknisi memasang dengan ukuran panjang kabel 100 meter, hal tersebut merupakan suatu resiko yang harus diterima PT INTI apalagi jika hal tersebut terjadi di beberapa area maka akan berdampak terhadap cost yang dikeluarkan perusahaan, dengan demikian dari permasalahan di atas maka diperlukan suatu pengendalian persediaan pada produk dropcable sehingga diharapkan dapat mengurangi terjadi nya stock out di beberapa produk dropcable, perusahaanpun dapat melakukan pemesenan kembali di titik safety stock yang ideal dan dapat mengontrol cost persediaan tahunan yang di keluarkan perusahaan. Mengendalikan persediaan atau inventory management yang tepat bukanlah hal yang mudah. Apabila jumlah persediaan terlalu besar mengakibatkan timbulnya biaya yang dikeluarkan terlalu besar, meningkatnya biaya penyimpanan seperti biaya pegawai, biaya operasional pabrik, biaya gedung, dll dan resiko kerusakan barang yang lebih besar. Namun bila persediaan terlalu sedikit mengakibatkan resiko terjadinya kekurangan persediaan (stock out) karena seringkali barang persediaan tidak dapat didatangkan secara mendadak yang menyatakan terhentinya proses produksi, tertundanya keuntungan, bahkan hilangnya pelanggan dan mempengaruhi terhadap produktifitas pekerjaan.

Persediaan merupakan suatu masalah yang kompleks dan penting untuk perusahaan karena menyangkut masalah-masalah optimasi dengan model kuantitatif sehingga diperlukan metode yang mengintegrasikan faktor-faktor model pesediaan.

\section{METODE PENELITIAN}

Salah satu keputusan yang harus diambil dalam manajemen persediaan adalah ukuran pesanan [1]. Untuk item yang permintaan atau kebutuhannya relatif stabil dalam jangka panjang, ukuran pesanan akan berimplikasi pada frekuensi pemesanan dan rata-rata persediaan yang akan disimpan oleh perusahaan. Menurut Pujawan [2] semakin kecil ukuran pesanan berarti semakin cepat persediaan habis sehingga semakin sering pesanan harus dilakukan. Karena biasanya ada ongkos tetap pemesanan yang terlalu besar. Sebaliknya, kalau pesanan dilakukan dalam ukuran besar, perusahaan akan lebih jarang 
memesan, namun secara rata-rata harus menyimpan persediaan dalam jumlah yang lebih besar. Model sederhana yang bisa digunakan untuk menentukan ukuran pesanan yang ekonomis adalah Model economic order quantity (EOQ). Model ini mempertimbangkan dua ongkos persediaan diatas, yakni ongkos pesan dan ongkos simpan. Ongkos pesan yang dimaksud adalah ongkos-ongkos tetap yang keluar setiap kali pemesanan dilakukan dan tidak tergantung pada ukuran atau volume pesanan. Sedangkan ongkos simpan adalah ongkos yang terjadi akibat perusahaan menyimpan barang tersebut selama suatu periode tertentu. Model ini merupakan salah satu model deterministik statis, yaitu tingkat permintaannya diketahui secara pasti dan bersifat konstan. Metode ini pertama kali diperkenalkan oleh Ford Harris dari Westinghouse pada tahun 1915. Meskipun terdapat berbagai macam asumsi yang harus dipenuhi dalam model EOQ, bagaimanapun juga EOQ adalah model manajemen persediaan yang dapat meminimumkan total biaya. Model EOQ dapat dilakukan dengan menggunakan asumsi sebagai berikut [3]; 1) Kebutuhan bahan baku dapat ditentukan, relatif tetap, dan terus menerus. 2) Tenggang waktu pemesanan dapat ditentukan dan relatif tetap. 3) Tidak diperkenankan adanya kekurangan persediaan; artinya setelah kebutuhan dan tenggang waktu dapat ditentukan secara pasti berarti kekurangan persediaan dapat dihindari. 4) Pemesanan datang sekaligus dan akan menambah persediaan. 5) Struktur biaya tidak berubah; biaya pemesanan atau persiapan sama tanpa memperhatikan jumlah yang dipesan, biaya simpan adalah berdasarkan fungsi linier terhadap rata-rata persediaan, dan harga beli atau biaya pembelian per unit adalah konstan (tidak ada potongan). 6) Kapasitas gudang dan modal cukup untuk menampung dan membeli pesanan.

Model EOQ mempunyai karakteristik tersendiri sesuai dengan parameter persoalan [4]. Pada dasarnya model persediaan dibagi menjadi dua kelompok utama, yaitu model deterministik dan model stokastik. Model deterministik semua parameternya-parameternya diasumsikan diketahui dengan pasti sedangkan model stokastik nilai-nilai parameternya tidak diketahui dengan pasti, berupa nilai-nilai acak.

\section{EOQ dengan adanya kebutuhan tetap.}

Model ini dapat diterapkan apabila kebutuhan-kebutuhan permintaan dimasa yang akan datang memiliki jumlah yang konstan dan relatif memiliki fluktuasi perubahan yang sangat kecil. Apabila jumlah permintaan telah diketahui, maka kita dapat mengasumsikan bahwa jumlah permintaan dan masa tenggang merupakan bilangan yang konstan dan dapat diketahui. Optimum order size dihitung dengan menganalisis total biaya persediaan. Total biaya pada suatu periode merupakan jumlah dari biaya penyimpanan dan biaya pemesanan atau biaya setup. Sehingga formulasi total biaya persediaan adalah sebagai berikut:

$$
T C=D H+\frac{Q}{2} H+\frac{D}{Q} S
$$

Maka formulasi persediaannya adalah;

$$
Q=\sqrt{\frac{2 S D}{H}}
$$

dimana:

$\mathrm{TC}=$ Total biaya persediaan (Rupiah)

$\mathrm{Q}=$ Jumlah pemesanan optimal $(\mathrm{Kg})$

$\mathrm{D}=$ Jumlah permintaan per tahun $(\mathrm{Kg})$

$\mathrm{H}=$ Ongkos simpan (Rupiah/unit/tahun)

$\mathrm{S}=$ Ongkos pemesanan (Rupiah/pesan).

Penelitian ini merupakan penelitian deskriptif, tahapan-tahapan pemecahan masalah adalah dengan melakukan peramalan (forecasting), dan pengendalian persediaan yaitu 
Pengendalian Persediaan Produk Drop Cable di Proyek Instalasi Kabel Rumah dan Migrasi Jaringan Area Bandung (Studi Kasus: PT Inti Persero)

Agung Dera Pradana, Leni Herdiani, Rohmana

menghitung EOQ, frekuensi pemesanan, titik pemesanan kembali serta total biaya tahunan [4]. Tahapan pemecahan masalah dapat dilihat pada Gambar 1 berikut ini:
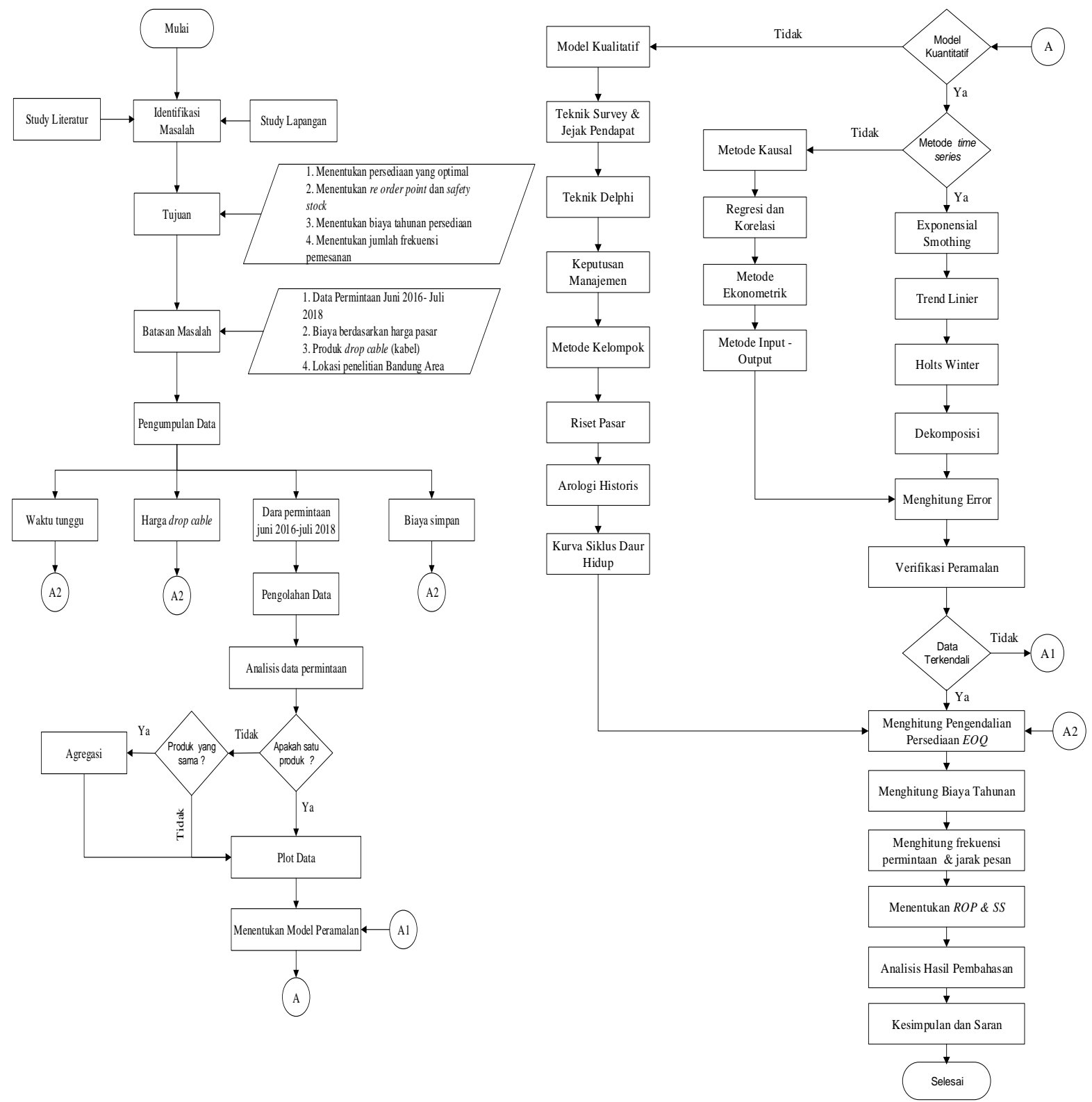

Gambar 1. Tahapan-tahapan Pemecahan Masalah

\section{HASIL DAN PEMBAHASAN}

\section{Analisis Faktor Konversi}

Dalam perhitungan nilai konversi hal yang dilakukan terlebih dahulu adalah menentukan variabel pembagi. Pemilihan variabel pembagi ini dilakukan secara random. Dalam penelitian ini variabel yang digunakan sebagai pembagi yaitu harga drop cable $55 \mathrm{~m}$, pemilihan veriabel harga drop cable $55 \mathrm{~m}$ sebagai faktor pembagi ini karena harga jenis drop cable 55m merupakan harga paling murah diantara harga drop cable yang lain.

\section{Analisis Motode Peramalan}

Ada 5 jenis produk yang akan dihitung tingkat persediaannya, sehingga dalam penentuan peramalan maka kelima jenis produk drop cable tersebut diagregatkan terlebih 
dahulu sehingga menjadi suatu gabungan produk menjadi satu. Pola data permintaan drop cable dapat dilihat pada Gambar 2 berikut ini.

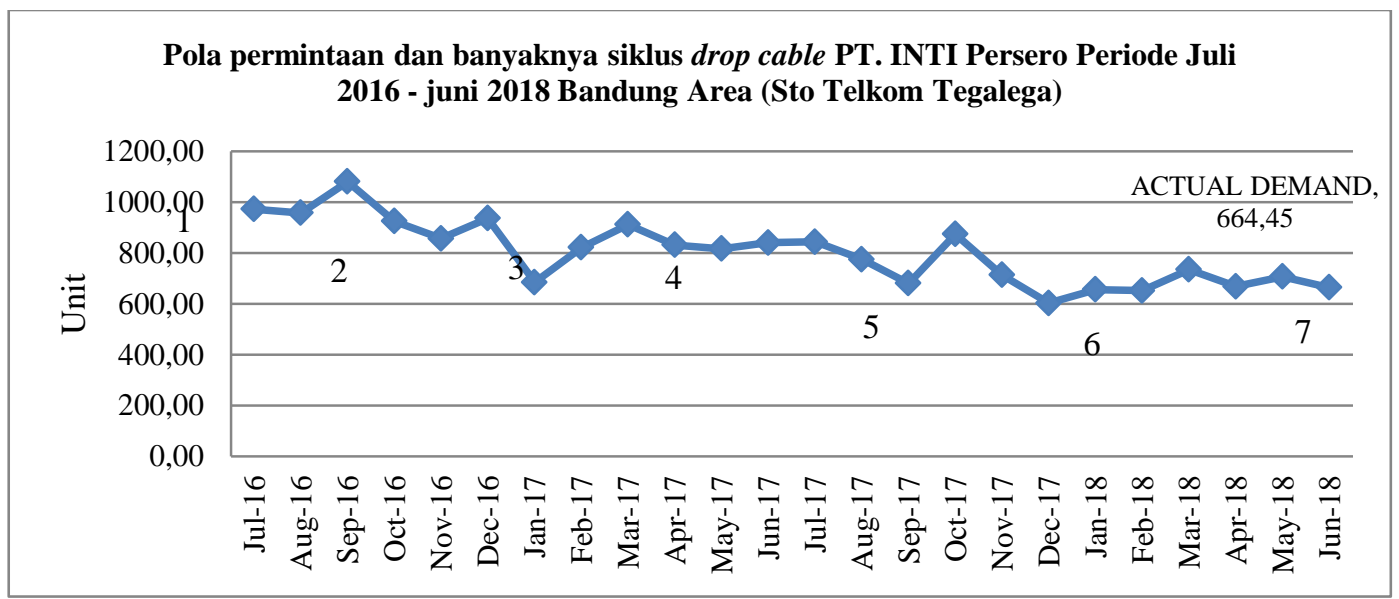

Gambar 2. Pola Permintaan dan Banyaknya Siklus Drop Cable

Berdasarkan pola Grafik permintaan berbentuk siklus musiman (seasonal) dengan pola trend menurun, sehingga digunakanlah metode time series dimana di dalamnya terdapat metode dekomposisi yang pada umumnya metode dekomposisi ini mencoba mengindentifikasikan kombinasi tiga komponen secara terpisah sebagai pola dasar, ketiga komponen tersebut adalah kecenderungan (trend), siklik (cyclical) dan faktor musiman (seaseonal factor). Namun untuk mengurangi kesalahan/error dalam menentukan metode peramalan maka di perlukan metode time series yang lainnya seperti metode Exponential Smoothing With Trend dan Triple Exponential Smoothing (Metode Holt's Winter) hal tersebut di lakukan agar adanya perbandingan sehingga dapat mengurangi kesalahan dalam penentuan model peramalan yang nantinya akan di pilih berdasarkan error terkecil. Setelah dilakukan perhitungan, terlihat bahwa metode peramalan yang dipilih adalah dekomposisi 3 bulanan. Pemilihan metode ini berdasarkan nilai error terkecil yaitu sebesar 48,84. Nilai error ini lebih kecil dibandingkan dengan nilai error metode Triple Eksponential Smoothing dan motode Eksponential Smoothing with Linier Trend yang mana nilai error masing-masing adalah 89,38 dan 51,84 [5]. Hasil perhitungan nilai error dari ketiga metode peramalan dapat dilihat pada Tabel 1.

Tabel 1. Rekapitulasi Error Peramalan Kumulatif

\begin{tabular}{lc}
\hline \multicolumn{1}{c}{ Metode Peramalan } & Mean Absolute Deviation (MAD) \\
\hline Dekomposisi 3 Bulanan & 48,84 \\
Eksponential Smoothing with Linier Trend & 51,84 \\
Triple eksponential smoothing & 89,38 \\
\hline
\end{tabular}

Selanjutnya nilai error hasil perhitungan dari dekomposisi 3 bulanan ini kemudian di plot ke dalam bentuk grafik yang dapat di lihat pada Gambar 3, untuk mengetahui apakah nilai tersebut berada dalam batas control atau tidak. Setelah dilakukan perhitungan terlihat bahwa nilai tersebut sudah berada dalam batas control. Maka tidak perlu merubah data ataupun metode peramalan karena nilai error sudah terkendali masuk dalam range batas kontrol atas dan bawah. 
Pengendalian Persediaan Produk Drop Cable di Proyek Instalasi Kabel Rumah dan Migrasi Jaringan Area Bandung (Studi Kasus: PT Inti Persero)

Agung Dera Pradana, Leni Herdiani, Rohmana

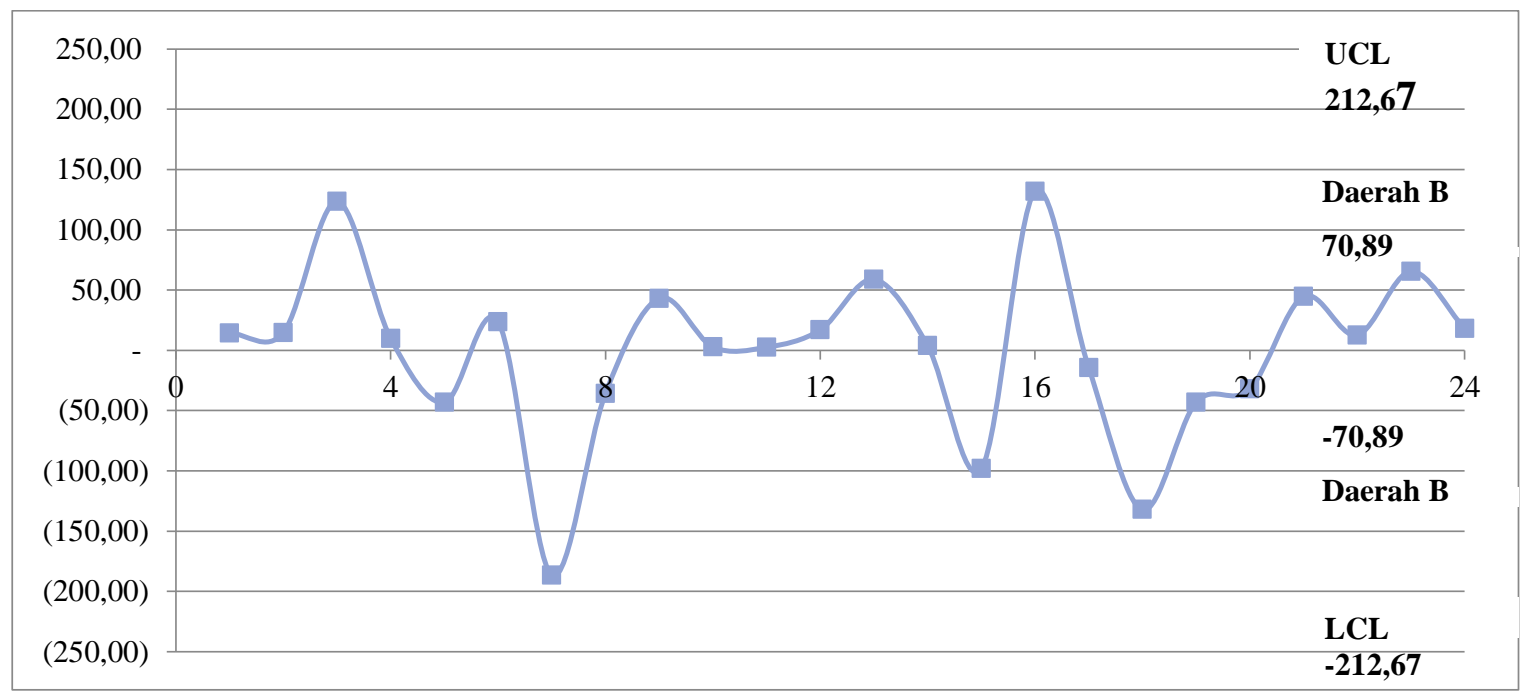

Gambar 3. Batas Kontrol Atas dan Bawah

\section{Pengendalian Persediaan}

Salah satu teori tentang persediaan ialah Economic Order Quantity (EOQ). Untuk menentukan perhitungan EOQ berikut diberikan data berdasarkan hasil perhitungan dan asumsi sebagai berikut $[1,6,7]$ :

Drop cable ukuran $55 \mathrm{~m}$

Annual Demand (D) = 2031 pcs (hasil peramalan Tabel 4.27)

Average Month Demand (d) = 192 unit (hasil peramalan $2301 / 12$ bulan)

Ordering Cost $(\mathrm{S}) \quad=$ Rp. 250.000,- per pesan

Holding Cost $(\mathrm{H}) \quad=$ Rp. 12000 per unit per tahun

Lead Time (L)

$=4$ hari $($ konversi 1 tahun $=0,014)$

Cost per Unit (C)

Working days

$=$ Rp. 137.500,-

$=301$ hari

Tingkat Ketelitian

$$
=5 \%
$$

Persediaan Optimal adalah:

$$
\begin{aligned}
& Q=\sqrt{\frac{2(R p \cdot 250.000,) \cdot(2031)}{R p \cdot 12000,-}} Q=\sqrt{95875} Q=309,637=310 \text { unit } \\
& \text { Frekuensi }=\frac{D}{Q}=\frac{2301}{310}=7,423=8 \mathrm{kali}
\end{aligned}
$$

Dikarenakan hasil dari nilai frekuensi terdapat nilai desimal maka perlu di lakukan perhitungan untuk nilai (Q) frekuensi terakhir sehingga sesuai dengan hasil peramalan permintaan (Q), adapun perhitungan sebagai berikut:

Nilai desimal frekuensi $\times \mathrm{Q}=0,423 \times 310=131$ (nilai $\mathrm{Q}$ untuk pemesanan frekuensi ke 8 atau terakhir)

$$
\text { Jarak }=\frac{\text { Jumlahhari }}{\text { Frekuensi }}=\frac{301}{7,423}=41,35 \text { hari } \approx 41 \text { hari }
$$

Selanjutnya adalah menentukan Total Cost. Perhitungan nilai total cost dilakukan dengan mengacu pada persamaan (1)

$$
T C=(2031) .(12000)+\frac{352}{2}(12000)+\frac{2031}{352}(250.000) T C=R p \cdot 31.327 .642,61
$$

Adapun titik pemesanan kembali dilakukan dengan menggunakan persamaan:

$$
\begin{aligned}
& R=\bar{d} \cdot L \\
& R=\frac{192}{12} \times 4 \quad R=63,92=64 \text { Units }
\end{aligned}
$$


Hasil perhitungan persediaan drop cable ukuran lainnya dapat dilihat pada Tabel 2 berikut ini.

Tabel 2. Hasil Perhitungan Pemesanan Optimal

\begin{tabular}{cccccccc}
\hline No & Jenis Drop Cable & D & Q & F & Jarak Pesan (Hari) & Total Cost & R \\
\hline 1 & 55 meter & 2301 & 310 & 8 & 41 & Rp. 31.327.642,61 & 64 \\
2 & 75 meter & 2034 & 291 & 7 & 43 & Rp. 27.901.422,39 & 57 \\
3 & 100 meter & 301 & 112 & 3 & 112 & Rp. $4.955 .874,99$ & 9 \\
4 & 125 meter & 195 & 90 & 3 & 139 & Rp. 3.421.665,38 & 6 \\
5 & 150 meter & 148 & 79 & 2 & 159 & Rp. 2.718.337,52 & 5 \\
\hline
\end{tabular}

Namun untuk menjaga adanya permintaan lebih dari produk dropcable ukuran $55 \mathrm{~m}$ pada saat pemesanan maka harus dilakukan penentuan safety stock (cadangan persediaan) dengan menggunakan persamaan:

$$
\begin{aligned}
S S & =z \alpha S \sqrt{ } L \\
& =1,65(18,27) \cdot \sqrt{0,014} \\
& =3,56=4 \text { (hasil di bulatkan) }
\end{aligned}
$$

Mencari nilai distribusi normal (z) dengan tingkat ketelitian 5\% di dapatkan dari hasil:

$$
\begin{aligned}
& Z=1-\alpha \\
& Z=1-0,05=0,9505 \\
& Z=1,65 \text { (hasil dapat di lihat di tabel } z \text { ) }
\end{aligned}
$$

Nilai standar deviasi dari produk drop cable $55 \mathrm{~m}$ adalah:

1. Harga rata-rata

$$
\bar{X}_{l}=\sum_{i=1}^{n=12} X_{I}=\frac{2301}{12}=191,75
$$

2. Standar deviasi sebenarnya

$$
S(\sigma)=\sqrt{\sum_{i=1}^{n=12} \frac{\left(X_{i}-\bar{X}\right)^{2}}{n-1}}=\sqrt{\frac{(218-191,75)^{2}+(213-191,75)^{2}+\cdots(214-191,75)^{2}}{12-1}}=18,27
$$

Hasil perhitungan Safety stock drop cable ukuran lainnya dapat dilihat dari Tabel 3 berikut ini:

Tabel 3. Hasil Perhitungan Safety stock drop cable

\begin{tabular}{ccccccc}
\hline No & Jenis Drop Cable & $\mathbf{D}$ & $\mathbf{Z}$ & $\mathbf{S}(\sigma)$ & $\sqrt{ } \boldsymbol{L}$ & $\mathbf{S S}$ \\
\hline 1 & 55 meter & 2301 & 1,65 & 18,27 & 0,118 & 4 \\
2 & 75 meter & 2034 & 1,65 & 16,15 & 0,118 & 4 \\
3 & 100 meter & 301 & 1,65 & 2,39 & 0,118 & 1 \\
4 & 125 meter & 195 & 1,65 & 1,55 & 0,118 & 1 \\
5 & 150 meter & 148 & 1,65 & 1,18 & 0,118 & 1 \\
\hline
\end{tabular}

Setelah didapatkan jumlah SS (safetystock) maka ada penambahan biaya yang harus dikeluarkan untuk produk drop cable $55 \mathrm{~m}$ diantaranya ialah biaya simpan dan harga drop cable.

Biaya safety stock $=$ harga drop cable $55 \mathrm{~m}+$ biaya simpan $\mathrm{x}$ Frekuensi

$$
\begin{aligned}
& =(\text { RP. } 137.500+\text { RP 12.000) } \times 8 \\
& =\text { RP. } 1.196 .000
\end{aligned}
$$

Hasil perhitungan biaya Safety stock drop cable ukuran lainnya adalah: 
Pengendalian Persediaan Produk Drop Cable di Proyek Instalasi Kabel Rumah dan Migrasi Jaringan Area Bandung (Studi Kasus: PT Inti Persero)

Agung Dera Pradana, Leni Herdiani, Rohmana

Tabel 4. Hasil Perhitungan biaya Safety stock drop cable

\begin{tabular}{ccccccc}
\hline No & $\begin{array}{c}\text { Jenis Drop } \\
\text { Cable }\end{array}$ & Harga Jual & $\begin{array}{c}\text { Biaya } \\
\text { Simpan }\end{array}$ & SS & F & Cost Safety Stock \\
\hline 1 & 55 meter & Rp 137.500,- & Rp 12.000,- & 4 & 8 & Rp 1.196.000,- \\
2 & 75 meter & Rp 187.500,-- & Rp 12.000,- & 4 & 7 & Rp 1.396.500,- \\
3 & 100 meter & Rp 250.000,- & Rp 12.000,- & 1 & 3 & Rp 786.000,- \\
4 & 125 meter & Rp 312.500,- & Rp 12.000,- & 1 & 3 & Rp 973.500,- \\
5 & 150 meter & Rp 375.000,- & Rp 12.000,- & 1 & 2 & Rp 774.000,- \\
\hline
\end{tabular}

\section{KESIMPULAN}

Dalam penelitian ini model yang digunakan ialah model deterministik, yaitu model yang mana lead time yang digunakan adalah konstan. Salah satu model deterministik adalah Economic Order Quantity (EOQ). Model EOQ yang digunakan adalah EOQ dengan adanya kebutuhan tetap. Penggunaan EOQ model ini dikarenakan kebutuhan-kebutuhan permintaan dimasa yang akan datang memiliki jumlah yang konstan dan relatif memiliki fluktuasi perubahan yang sangat kecil. Untuk menjaga adanya permintaan lebih seperti kebutuhan maintenance di area maka di tambahkan safety stock. Hasil perhitungan didapatkan biaya safety stock drop cable adalah Rp 1.196.000,- untuk jenis 55 meter dengan biaya simpan Rp 12.000,- dan Rp 774.000,- untuk jenis drop cable 150 meter.

\section{DAFTAR PUSTAKA}

[1].Bahagia, S. N. (2006). Sistem Inventori. Bandung: Penerbit ITB.

[2].Pujawan, 1.Y, 2005. Supply Chain Management. Surabaya: Guna Widya.

[3].Yamitt, Z. (2005). Menejemen Kualitas Produk dan Jasa. Edisi Pertama, Cetakan Keempat. Yogyakarta: Penerbit Ekonisia, UII Yogyakarta.

[4]. Aminudin. 2005. Prinsip-prinsip Riset Operasi. Jakarta: Erlangga.

[5]. Makridakis, S. (1988). Metode Dan Aplikasi Peramalan. Edisi kedua. Jakarta: Erlangga.

[6]. Baroto, T. (2002). Perencanaan Dan Pengendalian Produksi. Jakarta: Ghalia Indonesia.

[7].Diana Khairani Sofyan, S. (2013). Perencanaan Dan Pengendalian Produksi. Yogyakarta: Graha Ilmu.

[8].Rangkuti, F. (2007). Menejemen Persediaan. Jakarta: Rajawali Pers. 